\title{
Sacred Architecture in the Neapolitan Baroque Era. Space, Decorations, and Allegories
}

\author{
Elena Manzo ${ }^{1}$ \\ ${ }^{1}$ Professor at Department of Architecture and Industrial Design University of Campania "Luigi Vanvitelli"
}

Email: elena.manzo@unicampania.it

\begin{abstract}
In Naples (Italy), the passage from Renaissance to Baroque architectonic language could be identified between 1580 and 1612. During this era, one of the most significant topics of the architectonic research on the sacred space was the right compromise among the Counter-Reformation patterns, the central space and the oval plan. Giovanni Antonio Dosio and Dionisio di Bartolomeo were the most representative architects of this passage. They provide the access to new experimental varieties. So, when the architect Cosimo Fanzago arrived in Naples in 1612, the city was almost ready to use the emblematic ellipse plan of the Baroque, such as the churches Santa Maria della Sanita and San Giovanni dei Fiorentini by Fra' Nuvolo prove. Fanzago's architectonic research was followed by the studies by Bartolomeo and Francesco Antonio Picchiatti, father and son, up to Domenico Antonio Vaccaro that was the most representative director of the Baroque sacred space scene. Moving from the analysis and comparison of the most representative churches of Neapolitans Baroque era, the paper proposes an unedited studio about the evolution of sacred space's idea related to decoration, symbology and allegory, with a focus on Domenico Antonio Vaccaro's works, such as the churches of Santa Maria della Concezione in Montecalvario neighbourhood, San Michele Arcangelo in Naples' Piazza Dante, San Michele in Anacapri (on Capri Island), the Palazzo Abbaziale di Loreto and Saviour Church in San Guglielmo al Goleto Monastery, both near Avellino.
\end{abstract}

(C) 2019 The Authors. Published by IEREK press. This is an open access article under the CC BY license (https://creativecommons.org/licenses/by/4.0/).

\section{Keywords}

Baroque Neapolitan sacred architecture; Cosimo Fanzago; Domenico Antonio Vaccaro; Baroque polycentric spaces; metaphysical space; Bel Composto

\section{Introduction}

Historiography usually refers to the period between 1582 - the arrival of architect Giuseppe Valeriano - and 1623, that is when Cosimo Fanzago started working at the Certosa di San Martino (Charterhouse of St. Martin), as a transition era from the Neapolitan Counter-Reformation religious architecture to the Baroque (Cantone, 1984b), (Festa, 1997), (Electa Napoli, 2009). These were years in which the official culture was managed by Religious Orders and, above all, by the Society of Jesus. However, the Oziosi Academy and the Natural History Museum were starting to have a significant influence. Later, in fact, their studies on botanical and natural science even influenced the orientation of taste and artistic language.

Precisely, this transition period could be split in two further phases: the first one approximately up to 1612, when the Neapolitan architectural scene was dominated by Giuseppe Valeriano (1542-1596), the author of the Gesu` Nuovo church, and by Giuseppe Battista Cavagna (1545-1613), who renovated the church of San Paolo Maggiore (15891591), worked on the choir of Monteoliveto's church and designed Monte di Pieta 's Chapel (1601-1604). Spatial 
and linguistic elements of Counter- Reformation persisted in many important sacred buildings, such as the single nave covered by a barrel vault. The influence of Roman Classicism was therefore still evident but, at the same time, influences of Florentine tradition and, even more so, of the Brunelleschian language remained. All of this is clearly shown by the interior of the church of Girolamini, that was designed by Dionisio di Bartolomeo (1559-1638) and carried on Giovanni Antonio Dosio (1533-1609), and by Dosio's transformation of the Certosa di San Martino from 1589 to 1609 . However, whilst Dionisio di Bartolomeo and Dosio were the most representative architects of all that, they provided access to new experimental varieties.

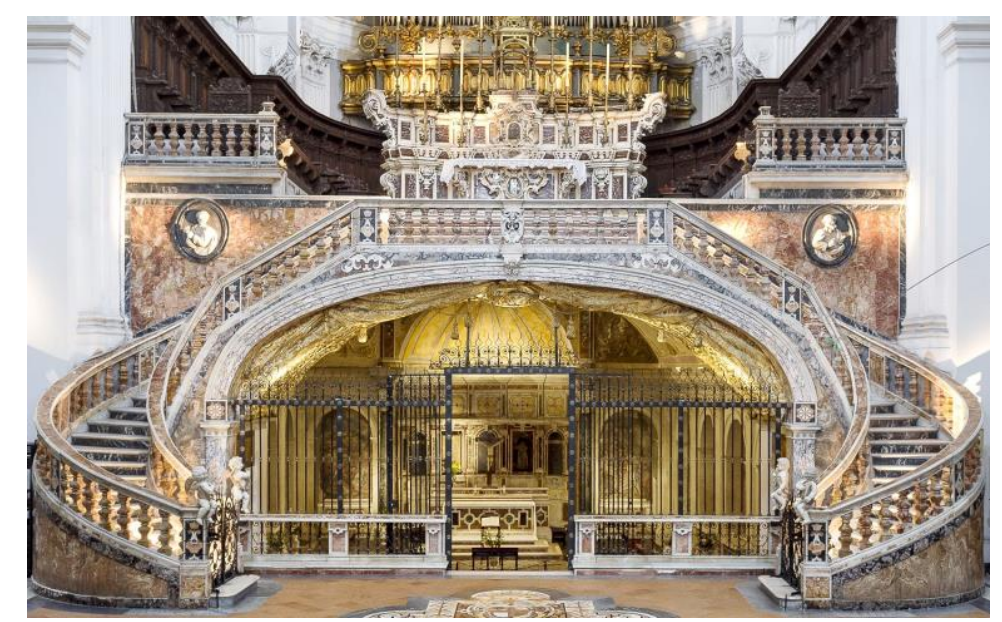

Figure 1. Naples, The Basilica of Santa Maria della Sanita` by Fra’ Nuvolo. The staircase

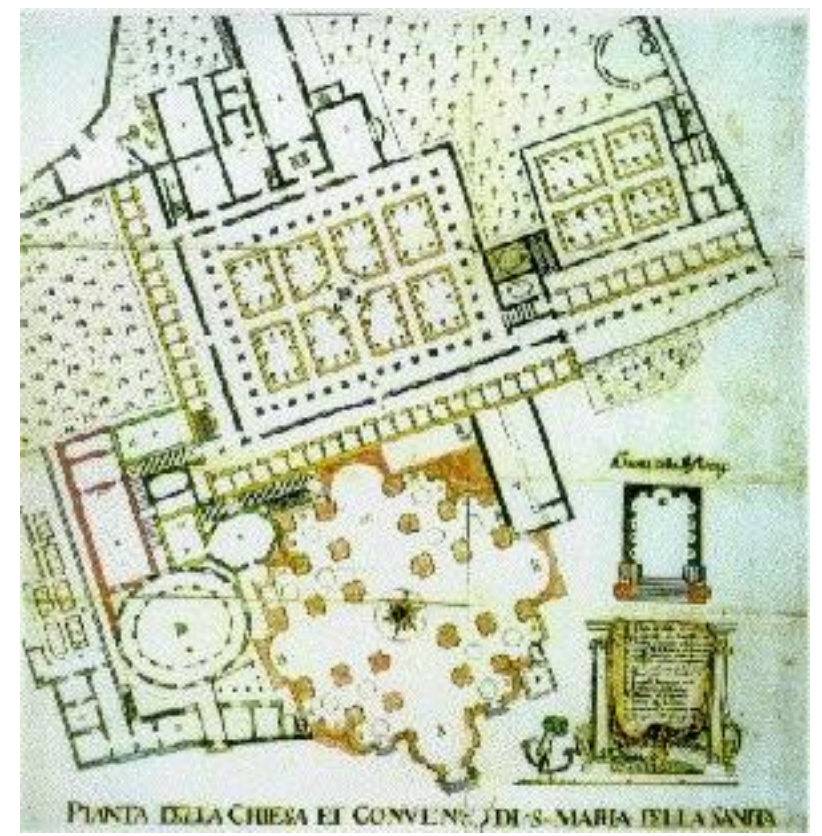

Figure 2. Naples, The Basilica of Santa Maria della Sanita` by Fra' Nuvolo. The staircase

In the ten years following the arrival of Cosimo Fanzago in Naples — that was around 1612 - architects Francesco Grimaldi (1543-1613), Giuseppe Donzelli (known as Fra' Nuvolo, 1570-1643) and Giovanni Giacomo Conforto (1569-1630) contributed to smooth out the transition of sacred architecture from the Post-Tridentine schemes to the Seventeenth century's new artistic forms. Suffice it to mention the influence of Vignola on Francesco Grimaldi, above all in the churches of S. Maria Degli Angeli a Pizzofalcone and Santissimi Apostoli, although many historians still doubt whether to ascribe these works to the latter.

However, the most significant example of this transition period is San Gennaro's Treasure Chapel, one of the most important works by Grimaldi, because, when the architect designed the plant he borrowed Bramante's planimetric pattern of St. Peter's in Vatican City but defining it in an octagonal pattern. Thereby, he started the Neapolitan architectonic research on sacred space towards one of the recurring themes of the Baroque and, that is, the "dy- namic" 
development of the central plan, which derives from the exploration of the right compromise among the CounterReformation patterns, the central space, and oval plan, as shown in the Basilica of Santa Maria Della Sanita 'by Fra' Nuvolo.

Regarding this, it was precisely noticed that plan of this church proves as Fra' Nuvolo has fully understood the space's multi-centrality designed by Donato Bramante for San Pietro, because «the geometric matrix is given by rhombuses and squares and by their intersection. The largest square encompasses the entire plan and the largest rhombus generates the centres of the apses and the relationship between the three domes of each sector. The smaller square corresponds to the central basin with the main dome and the corresponding rhombus determines the alignment of the domes» (Cantone, 1984a, (I), p.62). Nevertheless, even in this work - and more precisely, in the side vaults - he systematically uses the elliptical plan according to the Counter-Reformation meaning, as he did in the churches of San Giovanni dei Fiorentini (long gone), San Sebastiano and San Carlo all'Arena.

So, when the architect Cosimo Fanzago arrived in Naples in 1612, the city was almost ready to use the Baroque's emblematic ellipse plan and the polycentric space (Manzo, 2004 pp.59-63; 284-286).

Nevertheless, in the following years the Cosimo Fanzago's masterpieces were the best Neapolitan examples of "Unity of Visual Arts", which was the "new and revolutionary" attitude of the Baroque «to unify architecture with sculpture and painting so as to make of them all a beautiful whole», as Lavin wrote speaking about Gian Lorenzo Bernini or, more precisely, the "Bel Composto", as Filippo Baldinucci had just defined that (Lavin, 1980, p.198); about "Bel Composto", Lavin wrote paraphrasing Baldinucci. So see also (Baldinucci, 1682). In fact, we can find a good use of this theme in Fanzago's works, among them the Certosa di San Martino and the church of Santa Maria Egiziaca in Pizzofalcone neighbourhood (Brauen, 1973), (D’Agostino, 2011). However, in each of his works the decisive role was mainly played by the ornament, according with the theme of Rhetoric, which is one of the Baroque's subjects (Griseri, 1967), (Guglielminetti, 1999), (Anceschi, 1984). Specifically, he has often used the Allegory, the Metaphor and the Hyperbole, such as the sculptural decoration of Sant'Ignazio, San Bruno's Chappel, Santa Maria Della Anime Del Purgatorio ad Arco, which was designed by Giovanni Cola Di Franco and Giovan Giacomo Conforto, and, above all, of the Certosa di San Martino.

Thought, Fanzago's spatial patterns were still bound to traditional models, and they did not have the strength to expand beyond the bounds of Cartesian space. Therefore, the research on fac,ade was one of his most important contributions to Baroque Neapolitan sacred architecture because he reinterpreted late Neapolitan Mannerism's fac sade with arcaded portico, introducing the Serliana and transforming it into a dynamic diaphragm between inside space and outside space by games of concavity and convexity (Cantone, 1984).

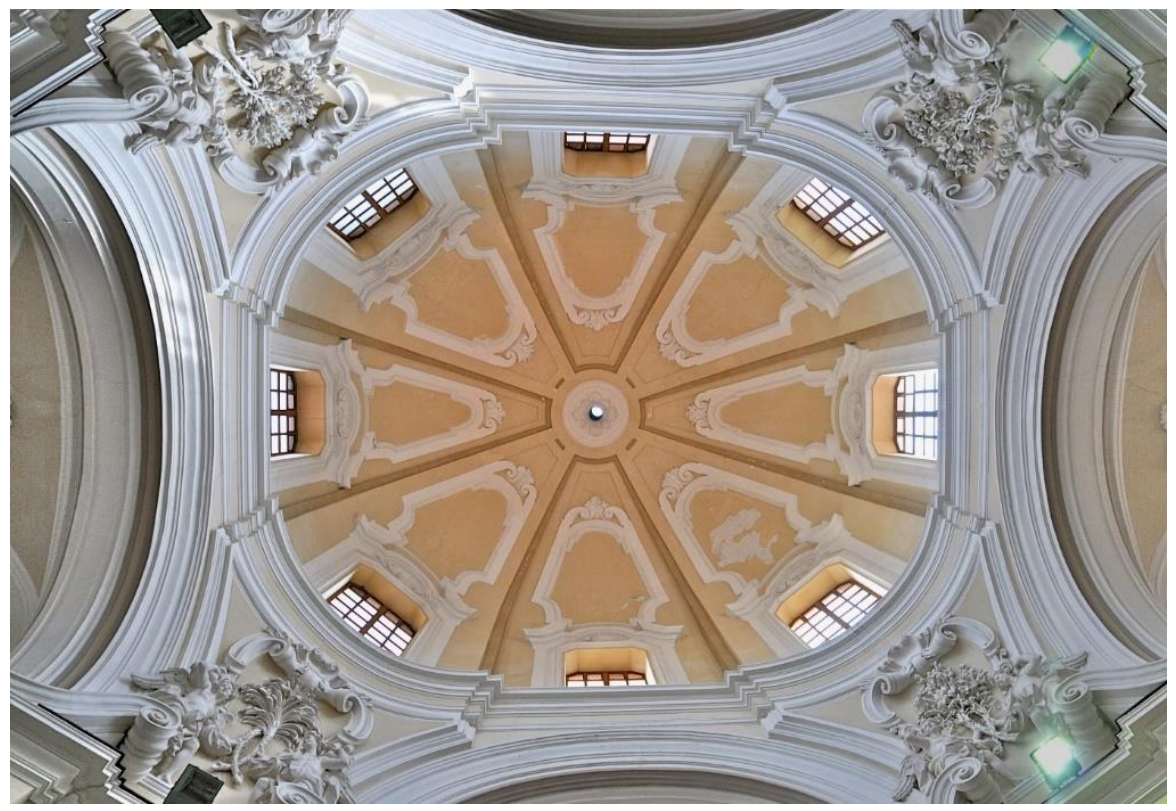

Figure 3. Naples, the dome of Santa Maria della Santissima Concezione in Montecalvario (Ph. Mimmo Ramires) 
Fanzago's architectonic research was followed by the studies by Bartolomeo and Francesco Antonio Picchiatti (15711643; 1617-1694), father and son, up to Domenico Antonio Vaccaro (1678-1745) that was the most repre- sentative director of the Baroque space scene (Pane, 1939, pp.155-167), (Ali, 1994, p.420), (Manzo, 1997), (Grav-agnuolo and Adriani, 2005).

Vaccaro was an artist with a multifaceted personality, who escapes any possibility of being caged in rigid categories or stylistic labels, such as Barocco, Tardobarocco or Rococo` (Ancheschi, 1945, pp.XVIII-XX), (Accademia nazionale dei Lincei, 1962), (Maravall, 1975), (Ancheschi, 1966), (Praz, 1960), (Blunt, 1975), (Schu“tz, 2004), (Snyder, 2005). The fluidity and the thematic articulation of his work intersect and connect to the complexity of the contemporary artistic debate, which was enriching of heterogeneous stimuli and complex solicitations, such as those coming from Central Europe - above all Germany and Austria — and by artists such as Fischer von Erlach and Johann Lucas von Hildebrandt.

Vaccaro, in fact, has often been resembled to them for the development of the Borrominian line, and the articulation of the polycentric spaces. On the other hand, he had learned from Bernini's works to use the light as if it had been a building material and had canalized the light beams to accentuate the observation's, hierarchies, to enhance chromatic effects, to emphasize the white of stuccoes, to smooth the structures, to accentuate the interior space's fluidity, accelerate its dynamic perception or to expand it (Manzo, 2014). One need only think of the church of San Michele Arcangelo in Naples' Piazza Dante, despite being one of his lesser known works.

It is a small church on a rectangular area. The works began in 1729 but ended in 1731 and the church was completed only in 1735 , when the facade was finished. The architect chose a Greek cross plan, whom he extended with an apse space on two sides correspondingly to the main altar. Inevitably, the interior space would have been too cramped and oppressive, so Vaccaro used diffuse light effects, intensified gradually upwards. In this way, these light effects break the limits of the structures and expand the space bounded by the dome. He juxtaposed a round dome with large windows to the tectonic and compact wall thickness of the octagonal drum. In this way, hidden sources of bundles of rays penetrate the church at the intersection of Greek cross plan's four arms and invade the interior. Here, the iridescent decoration of white stuccoes and the overhang of multilinear cornices enhance the chromatic effect on the walls.

One of the most significant Vaccaro's examples is undoubtedly Santa Maria Della Santissima Concezione in Montecalvario, which is also one of his most important works (Mormone, 1961, pp.147-149), (Pisani, 2005, pp.168- 169) (Pisani, 2005).

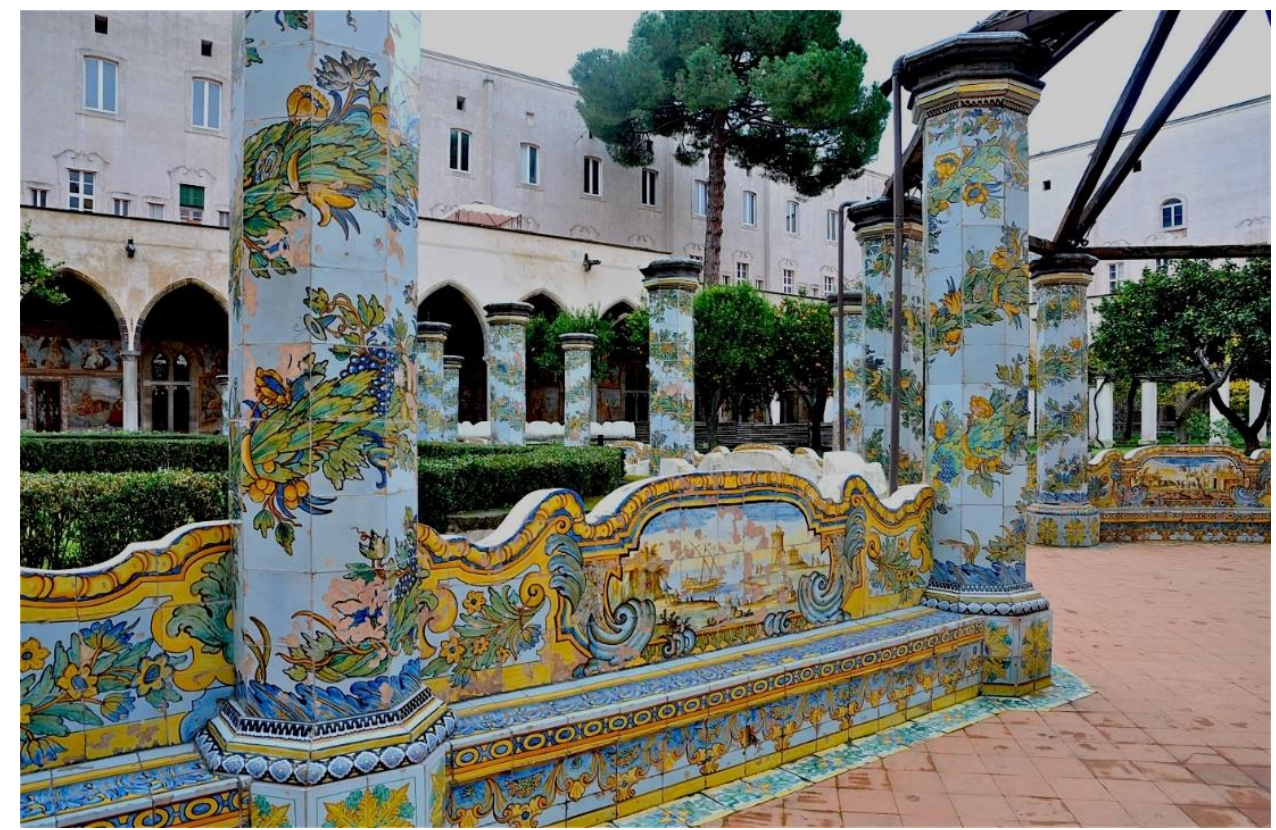

Figure 4. Naples, The Cloister in Santa Chiara Monastery. Pillars and canape's (Ph. Mimmo Ramires) 
In this church, Vaccaro held together the theme of the central octagonal plan with radial chapels - characteristic of many Neapolitan sacred buildings of the second half of the Seventeenth century -, the teachings of Borromini to turn domes on articulated plans arising from the aggregation of rigorous geometric figures, and the "Bel Com- posto".

Vaccaro imprinted plasticity and sinuosity on the architectural forms with the technical skill of the sculptor, whom he had learned at his father Lorenzo's atelier. He had known also Baroque of Rome thanks to him (Dominici, 1745), (Fittipaldi, 1980), (Abbate, 2002, vol. IV, p.155), (Manzo, 2004a), (Del Seicento, 1984, vol. II, pp.227-233). In addition, in Santa Maria Della Santissima Concezione Vaccaro completed the severe architecture of the whole with the metaphysical white of plaster and stucco and with a majolica floor, which had a brightly polychrome design. This latter has been composed by the painter's sensitivity that he had developed when he was a pupil of Francesco Solimena (Pavone, 2003).

We can find such deceptive devices in almost all the other Vaccaro's sacred architectures, such as the churches of

S. Michele Arcangelo in Naples' Piazza Dante and S. Michele in Anacapri (on Capri Island) or in the courtyard of the Palazzo Abbaziale di Loreto, near Avellino. In the latter, he uses the Borromini's bevelled concave corner, but emphasizing it.

The sacred and hidden space of the Cloister in Santa Chiara Monastery, his most famous work, is more an oxy- moron than an allegory (Tesauro, 1670), Tedesco (2003).

The work began in 1739, commissioned by the abbess Ippolita di Carmignano, who wanted to renew the Gothic "ancient" facies, which was prior widely deteriorated and disused, therefore it was no longer adequate to accommodate the young aristocrats forced to seclusion by their influential and rich families (Eisenhof, 1936), (Gallino, 1951), (Pane, 1955), (Jovino, 1983), (Donatone, 1995).

As is known, Vaccaro divided the pre-existing Gothic space with four avenues, orthogonal to each other but not axial with respect to the ogival arches of the portico. He marked the avenues with a sequence of octagonal pillars, covered by majolica, on which winding trellises of vine were drawn, but their leaves twisted in the opposite direction from that of the spiral. In this way, the design on majolica appears so dense and with so much bright and contrasting colours to cancel the plastic vision of the pillars to such an extent that the entire pergola structure seems to be supported by the spiral of the viticultural lattices. In addition, Vaccaro raised the walking surface of the avenues up to a central space, this also octagonal, which was the fulcrum of the entire composition. He delimited this space with a parapet and placed canape's on the inside. Everything was covered in majolica and decorated with landscape and everyday life scenes.

Vaccaro had transformed the medieval cloister into the most unusual painted architecture of the century and the whole was characterized by organicity, uniformity and synthesis of the arts. There was an entirely baroque spatial expansion in the inviolable closure of Santa Chiara's walls. This explosion was made up of perspectives and multiple visual escape points, which multiplied unreal perceptions in a continuous rebound of artifice and nature, infinity and limit. At the end of this perceptive experience, the visual synthesis was reached in a preferential axis, that is in the central avenue, extended from north to south, up to the impressive royal scale. Vaccaro, however, had done more: he had introduced the frivolity of life that throbbed to the outside, telling it about the backs of canape's and along the parapet of the garden. A worldly space, thus, had taken the place of the rigorous enclosure environment.

\section{Conclusion}

In conclusion, we advance the start of Neapolitan Baroque approximately at the eighties of XVI century, when the architectonical research began on the polycentric space of the sacred architecture. This on despite of both the most recent historiography that postpones the date at 1683 , and that most widespread historiographic theory that fixes the start of Neapolitan Baroque approximately at 1606 — when Caravaggio arrived in Naples — or at 1612 as specifically concern the architecture field.

On the other hand, although Fanzago was the first architect in Naples to have the capacity to hold together different arts in order to attain the Bernini's "Bel Composto", and also he gave innovative solutions to the fac,ade, Vaccaro 
was the most incisive director of the Baroque sacred space, and he played a decisive role about important topics, such as from translating baroque dynamism into masses and spaces set in motion. Rather, he preferred to create dynamic effects with structural elements, not ornament surfaces and the decorative allegories were always blended with his architectures.

Finally, also the luminous direction of Vaccaro belongs completely to the Baroque. Under his direction, what has been defined as "material in becoming", "bent and docile" pulsating energy is outlined, since he able to manage light with great skill in order to accentuate the fluidity of the structure and our sensations (Griseri, 1967, pp.5-6).

\section{References}

Abbate, F. (2002). Storia dellarte nellItalia meridionale. Il secolo doro. Roma: Donzelli.

Accademia nazionale dei Lincei (1962). Manierismo, barocco, rococo`: concetti e termini. Relazioni e discussioni. Roma.

Ali, S. (1994). Settecento napoletano. Sulle ali dell'aquila imperiale. 1707-34. Napoli: Electa Napoli.

Anceschi, L. (1984). L’idea del Barocco. Studi su un problema estetico. Bologna: Nuova Alfa. (Studi su un problema estetico).

Ancheschi, L. (1945). Rapporto sull'idea di Barocco. In Ors, E., editor, Del Barocco, pages XVIII-XX, Milano: Rosa e Ballo.

Ancheschi, L. (1966). Fenomenologia della critica: alcune appendici. Bologna: R. Patron.

Baldinucci, F. (1682). Vite del Cavalier Giovan Lorenzo Bernini, scultore, architetto, e pittore, scritta da Filippo Baldinucci Fiorentino alla Sacra e Reale Maesta` di Cristina Regina di Svezia. Firenze: .

Blunt, A. (1975). Neapolitan baroque and rococo architecture: Zwemmer.

Brauen, F. (1973). Cosimo Fanzago and Seventeenth century Neapolitan marble decoration. New York: . Cantone, G. (1984a). L'architettura. In Civilta`del Seicento a Napoli, Napoli; Napoli, pages 49-75: Electa. Cantone, G. (1984b). Napoli Barocca e Cosimo Fanzago. Napoli: Banco di Napoli. (II).

Cantone, G. (1984). L'architettura, in Civiltà del Seicento a Napoli, Napoli: Electa Napoli .

D’Agostino, P. (2011). Cosimo Fanzago scultore, Napoli: Paparo Edizioni.

Dominici, B. D. (1742-1745). Vite de' pittori, scultori, ed architetti napoletani non mai date alla luce da autore alcuno dedicate agli eccellentissimi signori, Eletti della fedelissima citta di Napoli. pages 1742-1745: stamperia Ricciardi.

Donatone, G. (1995). Il chiostro maiolicato di Santa Chiara. Napoli: ESI.

Eisenhof, A. D. E. (1936). Il chiostro maiolicato di Santa Chiara. Napoli: Arti grafiche D. Amodio. Fittipaldi, T. (1980). Scultura napoletana del Settecento. Napoli: Liguori.

Electa Napoli. (2009). Ritorno al Barocco: da Caravaggio a Vanvitelli. Napoli.

Gallino, T. M. (1951). Il chiostro maiolicato del Monastero di Santa Chiara in Napoli. Studio storico artistico. Napoli: .

Gravagnuolo, B. \& Adriani, F. (2005). Domenico Antonio Vaccaro. Napoli: Alfredo Guida editori. (Sintesi delle arti).

Gravagnuolo, B., \& Adriani, F. (2005). Domenico Antonio Vaccaro. Sintesi delle arti. Napoli: Alfredo Guida editori.

Griseri, A. (1967). Le metamorfosi del Barocco. Torino: Einaudi. Guglielminetti, E. (1999). Metamorfosi nell'immobilita'. Milano: Jaca Book.

in Festa, C. (1997). Capolavori in Festa. Effimero barocco a Largo di Palazzo. Napoli: Electa Napoli. Jovino, G. (1983). La Chiesa e il Chiostro maiolicato di S. Chiara in Napoli: ASMEZ.

Lavin, I. (1980). Bernini and the Unity of Visual Arts. New York-London: Oxford University Press.

Manzo, E. (1997). La merveille dei Principi Spinelli di Tarsia. Architettura e artificio a Pontecorvo. Pontecorvo, Napoli: ESI.

Manzo, E. (2004a). Dal Classicismo ordinato alla rivoluzione spaziale barocca. Napoli: ESI. Manzo, E. (2004b). Dal Classicismo “ordinato” alla rivoluzione spaziale barocca: ESI.

Manzo, E. (2014). Tra sacro e profano: metamorfosi barocche nelle architetture di Domenico Antonio Vaccaro. Acta/Artis. Estudis dArt Modern, pages $13-24$.

Maravall, J. A. (1975). La Cultura Del Barroco: Ana'lisis de una Estructura Histórica. Barcellona: Ariel.

Mormone, R. (1961). Domenico Antonio Vaccaro Architetto (I), in Napoli Nobilissima. Pane, R. (1939): .

Pane, R. (1955). Il chiostro di Santa Chiara in Napoli: . Pavone, M. A. (2003): Electa.

Pisani, S. (2005). Concezione a Montecalvario e la tradizione della pianta centrale. In Gravagnuolo, B. \& (ed.),

Praz, M. (1960). Introduzione al Barocco: Il Saggiatore.

Schütz, S. (2004). Estetica barocco: (Roma: Campisano editore). Snyder, J. R. (2005). L'estetica del Barocco. Bologna: Il Mulino: .

Tedesco, S. (2003). Le Sirene del Barocco. Il nuovo spazio dell'estetico nel dibattito italiano su dialettica e retorica. Aesthetica, 68, 68-68.

Tesauro, E. (1670). Il Cannocchiale Aristotelico. O sia Idea dellArguta et Ingeniosa Elocutione Che serve a tutta 1Arte Oratoria, Lapidaria; et Simbolica. Esaminata co Principij del divino Aristotele. Torino. 